\title{
Ethical challenges in inclusive education: The case of gifted students
}

\author{
Tirri, Kirsi
}

Emerald Group Publishing

2017

Tirri , K \& Laine , S 2017 , Ethical challenges in inclusive education: The case of gifted students . in A Gajewski (ed.), Ethics, Equity, and Inclusive Education . International Perspectives on Inclusive Education , vol. Volume 9 , Emerald Group Publishing , Bingley, UK , pp. 239-257 . https://doi.org/10.1108/S1479-363620170000009010

http://hdl.handle.net/10138/311839

https://doi.org/10.1108/S1479-363620170000009010

unspecified

acceptedVersion

Downloaded from Helda, University of Helsinki institutional repository.

This is an electronic reprint of the original article.

This reprint may differ from the original in pagination and typographic detail.

Please cite the original version. 


\section{ETHICAL CHALLENGES IN}

5

7

INCLUSIVE EDUCATION: THE

CASE OF GIFTED STUDENTS

11 Kirsi Tirri and Sonja Laine

\section{ABSTRACT}

17 Inclusion, defined as nondiscriminatory education for all, involves embracing gifted students whose special needs should be considered in

19 curriculum planning and in the teaching methods used. However, inclusion has often been connected with disability and special needs education.

21 It has been claimed that inclusion neglects the needs of the gifted. This chapter identifies ethical challenges in inclusive education, with gifted

23 students as a case example. Several critical misconceptions about gifted students and gifted education are identified as leading to ethical chal-

25 lenges for teachers. These misconceptions are discussed in the ethical framework of distributive justice in teaching, and recommendations are

27 given for ways to support teachers in meeting the needs of gifted students in inclusive educational settings.

29 Keywords: Inclusion; gifted students; curriculum planning; teaching methods; distributive justice; ethical challenges

Ethics, Equity, and Inclusive Education 
3 According to many leading educational scholars, teaching is a moral profession (Hansen, 2001; Sockett, 1993). Moreover, teachers' professional

5 values are believed to have direct influence on their pedagogical thinking and practice (Tirri, 2010, 2011). The primary goal of a teacher is to educate

7 the whole person of a child, regardless of background or academic achievement (Strike \& Soltis, 1985; Tirri, 2010). However, there are situations in

9 which teachers cannot allocate their time or resources equally to all students (Tirri, 1999). In these situations, teachers require guidelines to sup-

11 port their decision-making. In managing and resolving professional moral or ethical dilemmas, teachers usually refer to pedagogical principles, which

13 guide them in the decision-making process. In moral dilemmas that occur in practice, professionals need to decide how to create conditions for fair

15 treatment of all students. Deutsch (1985, p. 38) identified three different principles or values that can be used as a basis for distributing goods.

17 According to him, in cooperative relations where economic productivity is a primary goal, equity is typically the dominant principle of distributive

19 justice. In cooperative relations where fostering or maintaining positive social relations is the common goal, equality will be the dominant principle

21 in distributive justice. However, in cooperative relations where fostering of personal development and personal welfare is the common goal, need will

23 be the dominant principle of distributive justice.

In inclusive settings, teachers are often in situations where they need to

25 choose which principle of justice will guide their teaching behavior with diverse learners. We know from earlier research that making this kind of eth-

27 ical judgment is very difficult, and teachers are often unaware of the ethical implications of their actions (Jackson, Boostrom, \& Hansen, 1993). In

29 school life, the dilemmas teachers face call for complex decision-making, which requires them to reflect on whose needs they have to prioritize.

31 Accordingly, the value of need might be the right value for distributive justice in situations where the needs of gifted students are not met. For exam-

33 ple, a gifted student can feel unmotivated and may even underachieve because of a school environment that is not challenging. In this chapter, we

35 explore ethical challenges in inclusive education with emphasis on gifted students. We identify misconceptions about giftedness and gifted education

37 that might lead to the neglect of gifted students' needs in inclusive contexts. We discuss these misconceptions in light of current research on gifted stu-

39 dents and their education. Furthermore, we provide some recommendations that can help teachers meet the needs of gifted students in inclusive settings. 


\section{GIFTED STUDENTS IN INCLUSIVE EDUCATION}

3 According to a broad definition (Ainscow et al., 2006), inclusive education is defined as nondiscriminatory quality education for all (Saloviita, 2015;

5 UNESCO, 2009). This definition is important from the perspective of gifted students (Smith, 2006). It may be contended that the initial focus of inclu-

7 sion weighed heavily on disability (Arnesen, Mietola, \& Lahelma, 2007; Miles \& Singal, 2010; Saloviita, 2015); accordingly, in the minds of many

9 people, it refers solely to this particular group of students (Smith, 2006). We argue that inclusive education has neglected the needs of some other

11 groups, for example, the gifted. For that reason, it is imperative to examine the needs of gifted students in inclusive educational settings.

13 In this chapter, we acknowledge the broad definition of inclusion as highly important, yet our specific perspective is narrow, as we focus on

15 gifted students in inclusive settings. We believe that gifted students also have a need and a right to educational opportunities and learning that

17 meets their special needs and enhances their future. This is especially critical for gifted students who face disability, poverty, low socioeconomics,

19 poorly educated parents, and/or live in non-native-speaking homes. These gifted students depend heavily on the public education system to address

21 their needs in comparison to their upper-middle-class peers. If the school system does not address these needs, a group of individuals' full potential

23 will never be realized (Finn \& Wright, 2015). Further, education is a vehicle for the advancement of ones socioeconomic status (SES) and thus position

25 in society. An education that addresses the needs of gifted students has the capacity to improve the quality of life for this group.

27 Gifted students and gifted education are areas that divide the academic community, both in the field of education and in different countries. There

29 are many definitions of giftedness (Balchin, Hymer, \& Matthews, 2009; Moon \& Rosselli, 2000; Pfeiffer, 2002; Ziegler \& Raul, 2000), beliefs about

31 the meaning of giftedness, and perceptions as to how gifted individuals should be identified (Reis \& Renzulli, 2009). Furthermore, there is a wide

33 range of methods to support and identify giftedness (Dai \& Chen, 2013; Freeman, 2005; Larsen McClarty, 2016), and different school systems have

35 adapted their own definitions of giftedness. For example, in Australia the definition used is based on Gagné's Differentiated Model of Giftedness and

37 Talent (Australian Curriculum, Assessment and Reporting Authority (ACARA), 2015; Vialle \& Rogers, 2012). Based on this definition, gifted stu-

39 dents are "those whose potential is distinctly above average in one or more of the following domains of human ability: intellectual, creative, social and 
1 physical," while talented students are "those whose skills are distinctly above average in one or more areas of human performance" (ACARA, 2015). In

3 the definition given by the U.S. Federal Government, "the term 'gifted and talented' when used in respect to students, children, or youth means stu-

5 dents, children, or youth who give evidence of high performance capability in areas such as intellectual, creative, artistic, or leadership capacity, or in

7 specific academic fields, and who require services or activities not ordinarily provided by the school in order to fully develop such capabilities" (U.S. ED,

9 P.L. 103-382, Title XIV, p. 388, as cited in National Association for Gifted Children (NAGC), 2016). There are, however, significant differences in the

11 definitions of giftedness employed by education systems in the separate states in the United States (NAGC, 2016). In some countries, such as

13 Finland, there is no formal definition of giftedness (Laine, Kuusisto, \& Tirri, 2016; Laine \& Tirri, 2016; Tirri \& Kuusisto, 2013). Definitions are important

15 because they guide teachers and administrators in recognizing and actualizing gifted education practices in schools.

17 In addition to the multiplicity of definitions and the challenges associated with defining giftedness, the area includes many misconceptions. Such

19 misconceptions are incorrect beliefs or opinions, that may have some partial truths, but cannot be relied on or used as scientific guidelines for

21 informing an educational curriculum for the gifted. These misconceptions have been created and exist as though they explain a phenomenon that is

23 not easily understood (Kaplan, 2009). Nevertheless, misconceptions can influence gifted education practices. Their importance is emphasized by

25 two special issues devoted to the myths around the subject in Gifted Child Quarterly (1982, 2009). In the 1990s, Ellen Winner wrote a popular book,

27 Gifted Children: Myths and Realities, while more recently, Sak (2011) identified misconceptions that can be seen in the views of both laypeople and

29 academics when discussing gifted students. Below, some of these misconceptions are discussed in the framework of inclusive education, which chal-

31 lenge teachers ethically, for example, in relation to how they practice distributive justice in their classrooms.

ETHICAL CHALLENGES IN TEACHING GIFTED STUDENTS IN INCLUSIVE SETTINGS

39 Teaching involves intentional planning that acknowledges the needs of different learners. Gifted students, for example, may require more advanced 
1 teaching materials and a faster tempo in their studies compared to their peers. In daily practice, many teachers spending a considerable amount of

3 their time identifying and addressing the learning needs of their weakest or lowest achieving students, leaving little time for those who are gifted. Often,

5 the gifts and talents of gifted students are not identified at school or they are not supported effectively. There are many possible reasons for this, such as

7 lack of teachers' knowledge about gifted students and their special learning needs or lack of knowledge of evidence-based practices proven to be effec-

9 tive with gifted learners. Mainly for these reasons, some teachers have misconceptions about this group of students and their education.

Misconceptions Regarding Gifted Students

15 The Omniscient Person Belief

One misconception is that gifted students are omniscient, which means that

17 they have a general intellectual capacity that makes them gifted in everything (Sak, 2011). Winner (1996) called this the myth of global giftedness.

19 This misconception leads teachers to believe that gifted students with high IQs can learn anything and that they are gifted in all subject areas. Yet,

21 rarely are children gifted in all areas; uneven profiles are far more common (Winner, 1996). Furthermore, children can be gifted in one area and have a

23 learning disability in another area (Moon, 2009; Nicpon, Allmon, Sieck, \& Stinson, 2011; Reis \& McCoach, 2002; Winner, 1996). Such children are

25 called twice-exceptional students.

In inclusive classrooms, it may be perceived that globally gifted students

27 require limited teacher interaction and support. Moreover, these students may be used as peer tutors or teaching assistants (Laine \& Tirri, 2015;

29 Persson, 1998). Consequently, the teachers may ignore such gifted students, despite the fact that they might need help in many subject areas and or

31 skills development, such as, working as members of a team (Kuusisto \& Tirri, 2015) or in content areas where they experience difficulties.

33 This misconception can also neglect the needs of the twice-exceptional students, whose giftedness may never be recognized, as it is masked by a

35 learning disability. Based on this belief, we can identify an ethical challenge whereby teachers ignore the gifted students who do not fit the idea of omni-

37 science. Giftedness, however, should be seen as domain-specific (Gagné, 2005, 2010; Gardner, 1999; Subotnik, Olszewski-Kubilus, \& Worrell, 2011)

39 and gifted students as a group having various profiles and educational needs (Reis \& Renzulli, 2009). 


\section{Giftedness Equals a High IQ}

The idea that giftedness is equal to a high IQ is a misconception in the field

3 (Borland, 2009). This can be seen as a conservative and traditional view, one that dominated in the early stages in the field of education. However,

5 despite the fact that more recent theories and models have tried to eliminate the idea of a direct equivalence between giftedness and IQ (see, e.g.,

7 Sternberg \& Davidson, 2005) to consider more domain-specific models have been established (Gagné, 2005, 2010; Subotnik et al., 2011), this

9 notion remains strongly maintained by some educators (Borland, 2009; Subotnik et al., 2011). A number of problems result, at least in part, from

11 this misconception, including the underrepresentation of certain groups in gifted programs, inflexible cutoff scores for admission to gifted programs

13 and services (Borland, 2009), and the domains of giftedness that are currently supported in inclusive settings (cf. Gagné, 2005; Gardner, 1999).

15 Thus, the specific domains associated with giftedness might themselves be the ethical challenge in meeting the needs of gifted students. This mis-

17 conception might lead teachers to allocate more time and resources to students who demonstrate intellectual giftedness in particular areas associated

19 with the measurement of IQ, compared to others. For example, it is possible that a student with mathematical-logical intelligence (cf. Gardner, 1999)

21 stands out and is easier to identify and support than a student with interpersonal intelligence (Tirri \& Nokelainen, 2011) or one who is highly

23 creative.

\section{The Entity Belief}

Another misconception related to giftedness is that intelligence is innate and

27 entirely inherited (Sak, 2011). This belief is similar to what Dweck (2006) calls a fixed mindset (which is also called an entity theory of abilities).

29 According to this belief, basic human qualities like intelligence and personality are static and unalterable. Thus, giftedness is something inborn and

31 located somewhere in the brain. Therefore, it either exists or it does not, and the manifestation of giftedness depends on a person's inborn potential.

33 People with a growth mindset (which is also called an incremental theory of abilities) believe the opposite, namely, that intelligence, personality, and

35 abilities can be developed. This developmental view of giftedness is addressed in many currently relevant theories and definitions of giftedness

37 (Gagné, 2005, 2010; Reis \& Renzulli, 2009; Subotnik et al., 2011).

Our recent study on teachers' implicit theories revealed that Finnish tea-

39 chers $(N=212)$ have fixed, growth, or mixed mindsets regarding students' giftedness, beliefs that can potentially influence teaching and learning 
1 behaviors in schools (Laine et al., 2016). Parents, on the other hand, tend to have mainly fixed mindsets (Kuusisto \& Tirri, 2013). Empirical studies

3 show that students' mindsets shape their responses to academic challenges, independent of their actual intellectual ability. Students holding entity

5 beliefs show poorer self-efficacy, give up more easily, and adopt maladaptive strategies, also reflected in neural responses to coping with failure and

7 negative feedback (Yeager \& Dweck, 2012). These maladaptive responses are especially obstructive, given that increasingly, innovative and creative

9 thinking involving risk-taking and flexibility are essential learning skills for the twenty-first century (Dweck, 2009). Research has shown that students'

11 mindsets play a vital role in their learning success and in confronting educational challenges (Blackwell, Trzesniewski, \& Dweck, 2007; Mangels,

13 Butterfiels, Lamb, Good, \& Dweck, 2006; Yeager \& Dweck, 2012). Furthermore, the growth mindset, whether innate or taught, seems to lower

15 adolescents' aggression and stress levels and enhances their school performance (Yeager, Trzesniewski, Tirri, Nokelainen, \& Dweck, 2011).

17 It is very important to support gifted students in realizing their full potential and encouraging them to engage in the learning tasks required for

19 the global challenges of the twenty-first century (Tirri, 2016). The ethical issue related to an entity belief is that the teacher may not provide sufficient

21 challenges and opportunities for gifted learners. The students might be praised for their achievements, but they may not give enough demanding

23 opportunities to expand and grow, thus failing to achieve their highest potential. Furthermore, if intelligence is viewed as innate and entirely

25 inherited (Sak, 2011), students belonging to particular groups who have historically been disadvantaged in society may be overlooked or not con-

27 sidered as gifted.

29 The Syndromic Belief

According to this misconception, it is believed that most gifted individuals

31 possess a set of psychological symptoms such as paranoia, mania, depression, or antisocial tendencies. Those who encourage this belief usually

33 relate madness to genius, suggesting a thin line between insanity and genius (Sak, 2011). This misconception can also be called the disharmony hypoth-

35 esis; accordingly, it suggests that giftedness comes at a cost to the gifted (Baudson \& Preckel, 2013). Media are believed to play one of the most

37 influential roles in creating this belief by depicting geniuses as paradoxical personalities, as can be seen in the film, A Beautiful Mind (Sak, 2004), or

39 by generally representing the gifted as geniuses, oddballs, or nerds (Baudson \& Preckel, 2013; Meckstroth \& Kearney, 2007). 
In teaching for inclusion, this syndromic belief may lead to complete ignorance of gifted students and their needs. The syndromic belief can influence people to believe that most gifted students suffer from psychological problems. This may lead teachers and parents to believe that it is better not to identify or support gifted students at all, thereby protecting them from associated stigma or prejudices.

\section{High Ability Students Do Not Face Problems or Challenges}

9 The opposite of the syndromic belief is the idea that students with high ability do not face problems or challenges at all (Moon, 2009). In extreme

11 cases, such students can be viewed according to the harmony hypothesis in which gifted students are seen as leaders, role models, and humanitarians

13 (Baudson \& Preckel, 2013) or paragons of virtue (Persson, 1998). Winner (1996) also addresses the idealized picture of gifted children glowing with

15 psychological health, as being one of the myths in the field.

This misconception is closely related to the belief that gifted students will

17 succeed on their own, regardless of their school experiences. This can eventually lead teachers, other school personnel, and policymakers to avoid taking

19 responsibility for meeting the needs of the gifted (Moon, 2009). However, with regard to the academic needs of gifted students, researchers have sug-

21 gested that education should reflect their abilities, interests, and passions (Subotnik et al., 2011) by providing a curriculum that contains advanced

23 content and allows the students to excel at a faster pace than usual (Colangelo, Assouline, \& Gross, 2004; Tolppanen \& Tirri, 2014). Gifted stu-

25 dents have also been found to prefer homogeneous groups to heterogeneous ones, mainly for academic reasons (Adams-Byers, Whitsell, \& Moon, 2004).

27 In addition to academic needs, gifted students have a unique set of social needs. They require support from their families, teachers, and peers to real-

29 ize their full potential (Tolppanen \& Tirri, 2014). For instance, research shows that group membership affects a student's educational outcomes. If

31 the group devalues academic effort and achievement, it is possible that the gifted student will also devalue these things (Bliuc, Ellis, Goodyear, \&

33 Hendres, 2011). Furthermore, a supportive learning community helps the gifted student reach a higher level of independent learning, which can be

35 associated with academic success and satisfaction (Bliuc et al., 2011; Pike, Schroeder, \& Berry, 1997; Tolppanen \& Tirri, 2014; Zhao \& Kuh, 2004).

37 To conclude, in order to develop and stay motivated, gifted students need appropriate challenges and a supportive educational climate (Gagné, 2005,

39 2010; Moon, 2009). If their needs are not met, they might face boredom, frustration, and decreased motivation, and may develop maladaptive 
1 beliefs (Moon, 2009), all of which harm their development and later success. Furthermore, there are subgroups of the gifted, such as twice-

3 exceptional students, who can be seen as the most at-risk population among the gifted, as they are often not even identified or recognized as gifted.

5 The other danger in this misconception is that it might increase the use of gifted students as teachers' assistants, viewing them as a teacher's

7 helping resource (Laine \& Tirri, 2015; Persson, 1998). This misuse of gifted students is ethically questionable and problematic based on equal learning

9 opportunities regardless of the students' abilities or backgrounds (Tirri, 2010) every student has the same right to learn new things in school.

\section{Classless Belief}

13 This misconception implies that all children are gifted. According to Cross (2005) and Winner (1996), the belief is very common among school adminis-

15 trators and teachers. Especially in countries and educational systems that emphasize the value of equality, this belief may be a dominating one. Finland

17 is one of the Nordic welfare states in which equality and inclusiveness are the main guiding values in educational policy (Arnesen et al., 2007; Tirri \&

19 Kuusisto, 2013). Equality has been specifically manifested in taking care of the weakest students, such as children with learning difficulties (Tirri \&

21 Kuusisto, 2013). In the most recent cross-cultural study on teacher attitudes related to gifted education, Finnish teachers were the ones who most often

23 expressed a classless belief. The third most discriminating variable in the study was that "all children are gifted," a variable that differentiated Hong

25 Kong teachers from Western teachers. Asian teachers disagreed the most with this item, Finnish teachers agreed the most, and American teachers had

27 the most varied responses (Tirri, Tallent-Runnels, Adams, Yuen, \& Lau, 2002). The misconception that all children are gifted can also be found in

29 media discussions of giftedness, inclusion, and education (Laine, 2010).

The ethical challenge here is that, if teachers perceive all children as

31 gifted, then the requirement for additional supports for students is not required. Thus, this misconception has the potential to ignore the needs of

33 gifted students, disadvantaging them and preventing them from reaching their full potential (Winner, 1996).

Misconceptions about Gifted Education

\section{It Is Fair to Teach All Children the Same Way}

39 One of the critical misconceptions regarding (gifted) education is that it is fair to teach all children the same way (Cooper, 2009). This misconception 
1 originates from the idea that fair is synonymous with equal, meaning equal treatment of people with the same description or roles. However, the

3 assumption that students in a classroom are homogeneous is not valid, as is evident to parents, students, and effective teachers (Cooper, 2009).

5 Effective teachers are professionals who address students as individual learners and who have knowledge, a wide range of instructional techniques,

7 and mastery of specific tools for meeting different learning needs (Cooper, 2009). In empirical studies on the ideal qualities of an effective teacher for

9 the gifted, gifted students have been shown to value the personal and social qualities of teachers over intellectual qualities (Abel \& Karnes, 1994;

11 Shoshana, 2007; Vialle \& Quigley, 2002). Similar results have been found among non-gifted students, who likewise value the social qualities of their

13 teachers over their academic qualities. Hattie's (2009) synthesis of metaanalyses revealed that the most effective teachers are those "using particu-

15 lar teaching methods, teachers with high expectations for all students, and teachers who have created positive student-teacher relationship" (p. 126).

17 In inclusive education, it is critical that a homogeneous approach to teaching be avoided, because it is inadequate in meeting the diverse needs of

19 the learners (Forlin, 2010). The idea that a one-size-fits-all curriculum meets the needs of all learners should be abandoned (Dixon, Yssel, McConnell, \&

21 Hardin, 2014; Ferguson, 2008; Subban, 2006; Tomlinson, 1999, 2001). Rather, in inclusive environments the curriculum should be meaningful,

23 interesting, and engaging for every student (Ferguson, 2008), and the practices should enable all students to learn and develop (Roy, Guay, \& Valois,

25 2013). In order to address students' different needs, abilities, interests, and learning profiles, teachers should differentiate their teaching (Subban, 2006;

27 Tomlinson, 1999, 2001) in a way that is appropriate to each individual's abilities (Dixon et al., 2014; Tomlinson, 1999). The goal is to maximize each stu-

29 dent's learning opportunities (Tomlinson et al., 2003), success, and growth (Dixon et al., 2014). Similarly, differentiation means that there is no single

31 curriculum for gifted students. Appropriate challenges, such as greater depth and complexity, adjusted pace and greater independence, and instructional

33 support should be provided to gifted students, as well as to all other students in the classroom (Hertberg-Davis, 2009).

35 Connected to this belief in "fairness," some educators consider gifted education to be elitist, and they perpetuate the misconception that fairness

37 is achieved by teaching all children in the same way (Cooper, 2009). Teachers may allocate their resources to struggling students based on the

39 value of need, since the needs of special education students are believed to be more acute than those of others in the classroom. However, fair is not 
1 always equal and inclusion must address the individualized needs of all students, including the gifted. Accordingly, taking children's individual abili-

3 ties and needs into account is a practice based on every student's right. Ethically, it is the responsibility of the teacher to ensure that students are 5 afforded equitable (based on need) learning opportunities and experiences. Teachers must respect students' differences and respond accordingly to

7 diverse learning needs (Cooper, 2009).

Classroom Teachers Have the Time, the Skill, and the Will to

Differentiate Adequately

11 Differentiated instruction, described above, requires multiple skills on the part of the teacher, from identifying individual needs to responding to those needs effectively, and evaluating students' progress in multiple ways to further drive instruction. Thus, it is not surprising that many teachers feel that differentiation is a real challenge, and some may even resist it. This resistance can be caused by many factors; for example, some teachers view differentiation as being highly time consuming (Hertberg-Davis, 2009; VanTassel-Baska \& Stambaugh, 2005), others experience difficulty finding and utilizing resources, and some suggest that there is a lack of administrative support (VanTassel-Baska \& Stambaugh, 2005). Research indicates that teachers do not use differentiation on a regular basis (Archambault et al., 1993; Latz, Speirs Neumeister, Adams, \& Pierce, 2009; Westberg, Archambault, \& Brown, 1997; Westberg, Archambault, Dobyns, \& Salvin, 1993), and when they do, their focus is directed on struggling students (Brighton, Hertberg, Moon, Tomlinson, \& Callahan, 2005). There are also indications that in differentiating instruction, teachers may not use evidence-based best practices (Laine \& Tirri, 2016; Tirri \& Uusikylä, 1994). Thus, it seems that, while differentiation appears beneficial (HertbergDavis, 2009), specifically in inclusive classrooms, concerns about the time, knowledge, skill, and willingness of teachers must be acknowledged.

This does not mean that differentiation should be abandoned (HertbergDavis, 2009). It does, however, indicate that teachers need to be adequately prepared to work in inclusive settings (Forlin, 2010, 2012; KieltykaGajewski, 2012; Tirri \& Laine, 2015). In particular, teachers need to be educated about the unique needs of gifted students and how to best support their development in heterogeneous environments (Hertberg-Davis, 2009) using evidence-based best practices (Robinson, Shore, \& Enersen, 2007). Moreover, teachers need to be provided with adequate supports and resources for teaching in inclusive classrooms (Kieltyka-Gajewski, 2012). 
1 The ethical challenge here is that, if teachers are assumed to be differentiating, without adequate education or proper resources and supports,

3 it might be that the differentiation does not actualize in practice. As a result, the needs of the gifted students will not meet in the classroom.

5 This is a highly critical point from the perspective of gifted students who come from families with low SES, those who have immigrant status, or

7 those whose who are non-native speakers, as these children may not have parents or adult guardians to advocate for their educational needs or the

9 means to provide out-of-school educational supports. Consequently, if the needs of such students are not adequately met in the classroom, it

11 would be less likely that they would have access to equitable learning opportunities or experiences.

\section{CONCLUSIONS}

In this chapter, we discuss ethical challenges that may occur in inclusive

19 education, using gifted students as a case example. To achieve this goal, we have presented several misconceptions about gifted students and gifted

21 education in general; misconceptions that may present ethical challenges for teachers. We explore these misconceptions with an emphasis on the

23 needs of gifted students, who too often are neglected by the educational system. Professional ethics in teaching calls for equal attention to all stu-

25 dents and equitable educational opportunities and experiences. We have shown that the misconceptions identified here are themselves unethical

27 and cannot function as guidelines for a professional teacher. Thus, we have made some recommendations for teachers based on the misconcep-

29 tions presented in this chapter, which draw their attention to the diversity of gifted students and their needs in the classroom.

31 According to the omniscient person belief, gifted students are omniscient persons, meaning that gifted students have an intellectual capacity

33 that enables them to be gifted in all subjects and areas, capable of learning anything. The idea that giftedness is equivalent to a high IQ is also

35 one of the misconceptions in the field. According to Gardner's (1999) theory on multiple intelligences, giftedness is domain-specific and different

37 intelligences operationalize these domains. Based on these ideas, we have some recommendations for teachers for countering misconceptions related

39 to giftedness. Teachers should remember that: 
1. Giftedness should be seen as domain-specific and developmental.

2. The concepts of giftedness and talent need to be clearly defined and understood before educational decisions on students' giftedness are made.

The entity belief denotes that intelligence is innate and entirely inherited. This belief reflects a fixed mindset or an entity theory of abilities.

In this belief, basic human qualities like intelligence and personality are considered static and unalterable. Thus, giftedness is something one is born with and is located somewhere in the brain. This belief might lead a teacher to praise gifted students, yet at the same time prevent them from growing and developing to their optimal potential. In response to this misconception, we recommend that:

3. Gifted students need to be educated with an incremental view of giftedness that encourages challenging learning goals.

The syndromic belief suggests that most gifted people possess a set of psychological symptoms such as paranoia, mania, depression, or antisocial tendencies. The opposite of a syndromic belief is the idea that high ability students do not face problems or challenges at all. Both of these misconceptions may result in teachers not identifying gifted students and or failing to acknowledge the students' social and emotional needs. To avoid such difficulties, our recommendation for teachers is:

4. Gifted students need to be seen as a heterogeneous group of students who exhibit an almost unlimited range of personal characteristics.

According to the classless belief all students are gifted. The ethical challenge here is that if teachers believe that all children are gifted, then their needs are similar, and therefore differentiation and individualization are unnecessary. Such a belief may lead to the disadvantaging of students by failing to meet their specific learning needs. We have a recommendation for teachers to avoid this misconception:

5. Gifted students need to be identified and recognized.

The leading misconception related to gifted education is the belief that it is fair to teach all children the same way. This misconception builds on the idea of the equality of distributive justice. In inclusive settings, the value of equality does not meet the needs of diverse learners. Within an educational context, where fostering personal development and personal welfare are the common goals, need will be the dominant principle of distributive justice. This value guides teachers to identify the needs of every student, including those who are gifted. Ethically 
speaking, teachers are accountable to support all students, ensuring that equitable opportunities and experiences are afforded to all individuals. We recommend that teachers acknowledge their position of power in the classroom and take responsibility for the well-being, teaching, and learning of each student.

6. Gifted students need a teacher as much as other students do.

7. Gifted students' needs have to be met in classroom teaching.

8. Teachers should use evidence-based best practices in addressing gifted students' educational needs.

Finally, the misconception that classroom teachers have the time, the skill, and the will to differentiate adequately must be acknowledged, specifically by administrators and policymakers. According to empirical studies presented earlier in this chapter (Archambault et al., 1993; Brighton et al. 2005; Hertberg-Davis, 2009; Latz et al., 2009; Westberg \& Daoust, 2003), this is often untrue in the case of gifted students. Moreover, teachers may use differentiation practices that are ineffective (Stradling \& Saunders, 1993; Tomlinson et al., 2003). Teachers may also lack adequate resources, which can prevent differentiated teaching from being actualized in practice (Davalos \& Griffin, 1999; VanTassel-Baska \& Stambaugh, 2005). We have the following recommendations related to this belief:

9. Teachers need more education in the various ways to differentiate teaching for gifted students.

10. Teachers need adequate resources and supports in order to implement differentiation in practice.

Teachers are ethical professionals. As such, professional ethics should be reflected in the beliefs, values, and attitudes toward different learners in inclusive settings, as teachers engage in their practice.

The misconceptions and beliefs related to gifted students and gifted education, presented in this chapter, provide useful starting points for reflection and discussion related to teaching practice and teacher responsibilities in order to support educators working in inclusive settings. The goal of inclusive education is to afford nondiscriminatory quality education for all, with the aim of providing equitable learning opportunities and experiences for students. In this chapter, we focus on a specific diverse group of students, the gifted, whose needs may not consistently be met in inclusive classrooms. Ethically, the rights of these students are equally important and relevant, and therefore need to be addressed. 


\section{REFERENCES}

3 Abel, T., \& Karnes, F. A. (1994). Teacher preferences among the lower socioeconomic rural and suburban advantaged gifted students. Roeper Review, 17(1), 52-57.

5

ACARA. (2015). Australian curriculum. Retrieved from http://www.australiancurriculum.edu. au. Accessed on April 9, 2015.

Adams-Byers, J., Whitsell, S. S., \& Moon, S. M. (2004). Gifted students' perceptions of the academic and social/emotional effects of homogeneous and heterogeneous grouping. Gifted Child Quarterly, 48(1), 7-20.

Ainscow, M., Booth, T., Dyson, A., Farrell, P., Frankham, J., Gallannaugh, F., ... \& Smith, R. (2006). Improving schools, developing inclusion. London: Routledge.

Archambault, F., Westberg, K., Brown, S., Hallmark, B., Emmons, C., \& Zhang, W. (1993). Regular classroom practices with gifted students: Results of a national survey of classroom teachers differentiation: A literature review (p. 137) (Research Monograph 93102). Storrs: University of Connecticut, National Research Center on the Gifted and Talented.

Arnesen, A.-L., Mietola, R., \& Lahelma, E. (2007). Language of inclusion and diversity: Policy discourses and social practices in Finnish and Norwegian schools. International Journal of Inclusive Education, 11(1), 97-110.

Balchin, T., Hymer, B., \& Matthews, D. (2009). Introduction: Reflections on the road ahead. In T. Balchin, B. Hymer, \& D. Matthews (Eds.), The Routledge international companion to gifted education (pp. xx-xxiv). New York, NY: Routledge.

Baudson, T., \& Preckel, F. (2013). Teachers' implicit personality theories about the gifted: An experimental approach. School Psychology Quarterly, 28(1), 37-46.

Blackwell, L. S., Trzesniewski, K. H., \& Dweck, C. S. (2007). Implicit theories of intelligence predict achievement across an adolescent transition: A longitudinal study and an intervention. Child Development, 78(1), 246-263.

Bliuc, A., Ellis, R. A., Goodyear, P., \& Hendres, D. M. (2011). Understanding student learning in context: Relationships between university students' social identity, approaches to learning, and academic performance. European Journal of Psychology of Education, 26(3), 417-433.

Borland, J. H. (2009). Myth 2: The gifted constitute 3\% to $5 \%$ of the population. Moreover giftedness equals high IQ, which is a stable measure of aptitude. Spinal tap psychometrics in gifted education. Gifted Child Quarterly, 53(4), 236-238.

Brighton, C. M., Hertberg, H. L., Moon, T. R., Tomlinson, C. A., \& Callahan, C. M. (2005). The feasibility of high-end learning in a diverse middle school (Research Monograph RM05210). Charlottesville, VA: National Research Center on the Gifted and Talented.

Colangelo, N., Assouline, S., \& Gross, M. (2004). A nation deceived: How schools hold back America's brightest students (vol. 1). Retrieved from https://www.templeton.org/sites/ default/files/Nation_Deceived_Both_. Accessed on April 9, 2015.

Cooper, C. R. (2009). Myth 18: It is fair to teach all children the same way. Gifted Child Quarterly, 53(4), 283-285.

Cross, T. L. (2005). The social and emotional lives of gifted kids: Understanding and guiding their development. Waco, TX: Prufrock Press Inc.

Dai, D. Y., \& Chen, F. (2013). Three paradigm of gifted education: in search of conceptual clarity in research and practice. Gifted Child Quarterly, 57(3), 151-168. 
1 Davalos, R., \& Griffin, G. (1999). The impact of teachers' individualized practices on gifted students in rural, heterogeneous classroom. Roeper Review, 21(4), 308-314.

Deutsch, M. (1985). Distributive justice. A social-psychological perspective. London: Yale University Press.

Dixon, F. A., Yssel, N., McConnell, J. M., \& Hardin, T. (2014). Differentiated instruction, professional development, and teacher efficacy. Journal for the Education of the Gifted, $37(2), 111-127$.

Dweck, C. S. (2006). Mindset: The new psychology of success. New York, NY: Random House Publishing Group.

Dweck, C. S. (2009). Who will the 21st-century leaners be. Knowledge Quest, 38(2), 8-9.

9 Ferguson, D. L. (2008). International trends in inclusive education: The continuing challenge to teach each one and everyone. European Journal of Special Education Needs 11 Education, 23(2), 109-120.

Finn, C. E., \& Wright, B. L. (2015). Failing our brightest kids: The global challenge of educating

13 Forlin, C. (2010). Reframing teacher education for inclusion. In C. Forlin (Ed.), Teacher education of inclusion (pp. 3-12). New York, NY: Routledge.

15 Freeman, J. (2005). Permission to be gifted: How conceptions of giftedness can change lives. In R. J. Sternberg \& J. E. Davidson (Eds.), Conceptions of giftedness (2nd ed., pp. 80-97). New York, NY: Cambridge University Press.

Gagné, F. (2005). From gifts to talents: The DMGT as a developmental model. In R. J. Sternberg \& J. E. Davidson (Eds.), Conceptions of giftedness (2nd ed., pp. 98-119). New York, NY: Cambridge University Press.

Gagné, F. (2010). Motivation within the DMGT 2.0 framework. High Ability Studies, 21(2), $77-80$.

Gardner, H. (1999). Intelligence reframed: multiple intelligence for the 21st century. New York, NY: Basic Books.

23 Hansen, D. (2001). Teaching as a moral activity. In V. Richardson (Ed.), Handbook of research on teaching (4th ed., pp. 826-857). Washington, DC: American Educational Research 25 Association.

Hattie, J. (2009). Visible learning: A synthesis of over 800 meta-analyses relating to achievement. London: Routledge.

Hertberg-Davis, H. (2009). Myth 7: Differentiation in the regular classroom is equivalent to gifted programs and is sufficient: Classroom teachers have the time, the skill, and the will to differentiate adequately. Gifted Child Quarterly, 53(4), 251-253.

Jackson, P. W., Boostrom, R., \& Hansen, D. T. (1993). The moral life of schools. San Francisco, CA: Jossey-Bass.

Kaplan, S. (2009). Myth 9: There is a single curriculum for the gifted. Gifted Child Quarterly, 53(4), 257-258.

Kieltyka-Gajewski, A. (2012). Ethical challenges and dilemmas in teaching students with special needs in inclusive classrooms: Exploring the perspectives of Ontario teachers. Unpublished doctoral dissertation. University of Toronto, Toronto.

Kuusisto, E., \& Tirri, K. (2013). Growth mindset of teachers and parents: A case study of Finnish schools. In The Committee for the Future (Ed.), Uusi oppiminen [New learning] (pp. 14-34). The Parliament of Finland: Helsinki.

Kuusisto, E., \& Tirri, K. (2015). Disagreements in working as a team: A case study of gifted science students. Revista de educacion, 368, 10-32. 
1 Laine, S. (2010). The Finnish public discussion of giftedness and gifted children. High Ability Studies, 21(1), 63-76.

Laine, S., Kuusisto, E., \& Tirri, K. (2016). Finnish teachers' conceptions of giftedness. The Journal for the Education of the Gifted, 39(2), 151-167.

Laine, S., \& Tirri, K. (2016). How Finnish elementary school teachers meet the needs of their gifted students. High Ability Studies, e-publication ahead of print.

Larsen McClarty, K. (2016). Global gifted education: How international views of giftedness influence educational practices and student performance. Paper presented at the annual meetings of the American Educational Research Association, April 2016, Washington, DC.

9 Latz, A. O., Speirs Neumeister, K. L., Adams, C. M., \& Pierce, R. L. (2009). Peer coaching to improve classroom differentiation: Perspectives from project CLUE. Roeper Review, $1131(1), 27-39$.

Mangels, J., Butterfiels, B., Lamb, J., Good, C., \& Dweck, C. S. (2006). Why do beliefs about intelligence influence learning success? A social cognitive neuroscience model. Social Cognitive and Affective Neuroscience, 1(2), 75-86.

Meckstroth, B., \& Kearney, K. (2007). Indecent exposure: Does the media exploit highly gifted children? [Electronic version]. Retrieved from http://www.hoagiesgifted.org/indecent_ exposure.htm. Accessed on April 9, 2016.

Miles, S., \& Singal, N. (2010). The education for all and inclusive education debate: Conflict, contradiction or opportunity. International Journal of Inclusive Education, 14(1), 1-15.

Moon, S. M. (2009). Myth 15: High-ability students don't face problems and challenges. Gifted Child Quarterly, 53(4), 274-276.

Moon, S. M., \& Rosselli, H. C. (2000). Developing gifted programs. In K. A. Heller, F. J. Mönks, \& R. F. Subotnik (Eds.), International handbook of giftedness and talent (pp. 499-521). Amsterdam: Elsevier Science.

NAGC. (2016). Definitions of giftedness. Retrieved from http://www.nagc.org/resources-publications/resources/definitions-giftedness. Accessed on April 9, 2016.

Nicpon, M. F., Allmon, A., Sieck, B., \& Stinson, R. D. (2011). Empirical investigation of twice exceptionality: Where have we been and where are we going. Gifted Child Quarterly, 55(1), 3-17.

Persson, R. (1998). Paragons of virtue: Teachers' conceptual understanding of high ability in an egalitarian school system. High Ability Studies, 9(2), 181-196.

Pfeiffer, S. I. (2002). Identifying gifted and talented students: Recurring issues and promising solutions. Journal for Applied School Psychology, 19(1), 31-50.

Pike, G., Schroeder, C., \& Berry, T. (1997). Enhancing the educational impact of residence halls: The relationship between residential learning communities and first-year college experiences and persistence. Journal of College Student Development, 38(6), 609-621.

Reis, S. M., \& McCoach, D. B. (2002). Underachievement in gifted and talented students with special needs. Exceptionality, 10(2), 113-125.

Reis, S. M., \& Renzulli, J. S. (2009). Myth 1: The gifted and talented constitute one single homogeneous group and giftedness is a way of being that stays in the person over time and experiences. Gifted Child Quarterly, 53(4), 233-235.

Robinson, A., Shore, B. M., \& Enersen, D. L. (2007). Best practices in gifted education: An evidence-based guide. Waco, TX: Prufrock Press Inc. 
1 Roy, A., Guay, F., \& Valois, P. (2013). Teaching to address diverse learning needs: Development and validation of a differentiated instruction scale. International Journal of Inclusive Education, 17(11), 1186-1204.

Sak, U. (2004). About creativity, giftedness and teaching the creatively gifted in the classroom. Roeper Review, 26(4), 216-222.

Sak, U. (2011). Prevalence of misconceptions, dogmas, and popular views about giftedness and intelligence: A case from Turkey. High Ability Studies, 22(2), 179-197.

Saloviita, T. (2015). Measuring pre-service teachers' attitudes towards inclusive education: Psychometric properties of the TAIS scale. Teaching and Teacher Education, 52, 66-72.

Shoshana, R. (2007). Who is the best teacher? Do different kinds of students have different preferences? In K. Tirri, \& M. Ubani (Eds.), Holistic education and giftedness (pp. 60-71). Publication of the Department of Practical Theology, University of Helsinki. Espoo: Multiprint.

Smith, C. M. M. (2006). Principles of inclusion: Implications for able learners. In C. M. M. Smith (Ed.), Including gifted and talented: Making inclusion work for more gifted and able learners. London: Routledge.

Sockett, H. (1993). The moral base for teacher professionalism. New York, NY: Teachers College Press.

Sternberg, R. J., \& Davidson, J. E. (2005). Conceptions of giftedness (2nd ed.). New York, NY: Cambridge University Press.

Stradling, B., \& Saunders, L. (1993). Differentiation in practice: Responding to the needs of all pupils. Educational Research, 35(2), 127-137.

19 Strike, K., \& Soltis, J. (1985). The ethics of teaching. New York, NY: Teachers College Press.

Subban, P. (2006). Differentiated instruction: A research basis. International Education Journal, 7(7), 935-947.

Subotnik, R. F., Olszewski-Kubilus, P., \& Worrell, F. C. (2011). Rethinking giftedness and gifted education: A proposed direction forward based on psychological science. Psychological Science in the Public Interest, 12(1), 3-54.

Tirri, K. (1999). Teachers' perceptions of moral dilemmas at school. Journal of Moral Education, 28(1), 31-47.

Tirri, K. (2010). Teachers' values underlying their professional ethics. In T. Lovat et al. (Eds.), International handbook on values education and student well-being (pp. 153-163). New York, NY: Springer.

Tirri, K. (2011). Holistic school pedagogy and values: Finnish teachers' and students' perspectives. International Journal of Educational Research, 50(4), 159-165.

Tirri, K. (2016). Holistic perspectives on gifted education for the 21st century. In D. Ambrose. \& R. Sternberg (Eds.), Giftedness and talent in the 21st century: Adapting to the turbulence of globalization (pp. 101-111). Rotterdam: Sense Publishers.

Tirri, K., \& Kuusisto, E. (2013). How Finland serves gifted and talented pupils. The Journal for the Education of Gifted, 36(1), 84-96.

Tirri, K., \& Nokelainen, P. (2011). Measuring multiple intelligences and moral sensitivities in education. Rotterdam: Sense Publishers.

Tirri, K., Tallent-Runnels, M., Adams, A., Yuen, M., \& Lau, P. (2002). Cross-cultural predictors of teachers' attitudes toward gifted education: Finland, Hong Kong, and the United States. Journal for the Education of the Gifted, 26(2), 112-131.

Tirri, K., \& Uusikylä, K. (1994). How teachers perceive differentiation of education among the gifted and talented. Gifted and Talented International, 9(2), 69-73. 
1 Tolppanen, S., \& Tirri, K. (2014). How an enrichment summer program is meeting the expectations of gifted science students: A case study from Finland. International Journal for Talent Development and Creativity, 2(1), 103-115.

Tomlinson, C. A. (1999). The differentiated classroom: Responding to the needs of all learners. Upper Saddle River, NJ: Pearson Education.

Tomlinson, C. A. (2001). How to differentiate instruction in mixed-ability classrooms (2nd ed.). Upper Saddle River, NJ: Pearson Education.

Tomlinson, C. A., Brighton, C., Hertberg, H., Callahan, C. M., Moon, T. R., Brimijoin, K., ... \& Reynolds, T. (2003). Differentiating instruction in response to student readiness, interest, and learning profile in academically diverse classrooms: A review of literature. Journal for the Education of the Gifted, 27(2), 119-145.

UNESCO. (2009). Policy guidelines on inclusion in education. Paris: UNESCO. Retrieved from http://unesdoc.UNESCO.org/images/0017/001778/177849e.pdf. Accessed on April 9.

VanTassel-Baska, J., \& Stambaugh, T. (2005). Challenges and possibilities for serving gifted learners in the regular classroom. Theory into Practice, 44(3), 211-217.

13 Vialle, W., \& Quigley, S. (2002). Does the teacher of the gifted need to be gifted? Gifted and Talented International, 17, 85-90.

15 Vialle, W., \& Rogers, K. (2012). Gifted, talented, or educational disadvantage? The case for including 'giftedness' in teacher education programs. In C. Forlin (Ed.), Future directions for inclusive teacher education (pp. 114-122). New York, NY: Routledge.

Westberg, K. L., Archambault, F. X., \& Brown, S. W. (1997). A survey of classroom practices with third and fourth grade students in the United States. Gifted Education International, 12(1), 29-33.

Westberg, K. L., Archambault, F. X., Dobyns, S. M., \& Salvin, T. J. (1993). An observational study of instructional and curricular practices used with gifted and talented students in regular classrooms (Research Monograph 93104). Storrs: National Research Center on the Gifted and Talented, University of Connecticut.

Westberg, K. L., \& Daoust, M. E. (2003). The results of the replication of the classroom practices survey replication in two states. Storrs: National Research Center on the Gifted and Talented, University of Connecticut.

Winner, E. (1996). Gifted children: Myths and realities. New York, NY: Routledge.

27 Yeager, D. S., \& Dweck, C. S. (2012). Mindsets that promote resilience: When students believe that personal characteristics can be developed. Educational Psychologist, 47(4), $302-314$.

29 Yeager, D., Trzesniewski, K. H., Tirri, K., Nokelainen, P., \& Dweck, C. S. (2011). Adolescents' implicit theories predict desire for vengeance after remembered and hypothetical peer conflicts. Developmental Psychology, 47(4), 1090-1107.

Zhao, C., \& Kuh, G. D. (2004). Adding value: Learning communities and student engagement. Research in Higher Education, 45(2), 115-138.

Ziegler, A., \& Raul, T. (2000). Myth and reality: A review of empirical studies on giftedness. High Ability Studies, 11(2), 113-236. 
AUTHOR QUERY FORM

\begin{tabular}{|l|l|l|}
\hline & Book: IPIE-V009-3611411 & \multicolumn{1}{|c|}{$\begin{array}{c}\text { Please e-mail or fax your responses } \\
\text { and any corrections to: }\end{array}$} \\
Chapter: CH010 & $\begin{array}{l}\text { E-mail: } \\
\text { Fax: }\end{array}$ \\
\hline
\end{tabular}

Dear Author,

During the preparation of your manuscript for typesetting, some questions may have arisen. These are listed below. Please check your typeset proof carefully and mark any corrections in the margin of the proof or compile them as a separate list.

\section{Disk use}

Sometimes we are unable to process the electronic file of your article and/or artwork. If this is the case, we have proceeded by:

\section{Scanning (parts of) your article $\square$ Rekeying (parts of) your article}

Scanning the artwork

\section{Bibliography}

If discrepancies were noted between the literature list and the text references, the following may apply:

The references listed below were noted in the text but appear to be missing from your literature list. Please complete the list or remove the references from the text.

UNCITED REFERENCES: This section comprises references that occur in the reference list but not in the body of the text. Please position each reference in the text or delete it. Any reference not dealt with will be retained in this section.

Queries and/or remarks

\begin{tabular}{|l|l|l|}
\hline Location in Article & \multicolumn{1}{|c|}{ Query / remark } & Response \\
\hline AU:1 & $\begin{array}{l}\text { As per style, the right running head } \\
\text { is shortened to fit the space. Please } \\
\text { check the suggested right running } \\
\text { head for correctness. }\end{array}$ & \\
\hline AU:2 & $\begin{array}{l}\text { References "Laine and Tirri (2015); } \\
\text { Forlin (2012); Tirri and Laine } \\
\text { (2015)" have not been provided in } \\
\text { the list. Please provide the reference } \\
\text { details. }\end{array}$ & \\
\hline
\end{tabular}




\begin{tabular}{|l|l|l|} 
AU:3 & $\begin{array}{l}\text { The spelling of the author names in } \\
\text { the text has been changed to } \\
\text { Meckstroth and Kearney (2007); } \\
\text { Roy, Guay, \& Valois, (2013); } \\
\text { Westberg, Archambault, Dobyns, } \\
\text { and Salvin (1993) to match the } \\
\text { reference list. Please check the } \\
\text { spelling, and correct if necessary. }\end{array}$ & \\
\hline AU:4 & $\begin{array}{l}\text { Please update reference Laine \& } \\
\text { Tirri (2016). }\end{array}$ & \\
\hline AU:5 & $\begin{array}{l}\text { Please list all names for reference } \\
\text { Tirri, K. (2010) up to 6 editors. }\end{array}$ & \\
\hline
\end{tabular}

